\title{
Effect of Sage Extract on Alkaline Phosphatase, Enterocyte Proliferative Activity and Growth Performance in Chickens
}

\author{
Mikuláš Levkut, Andrej Marcin, L'udovít Lenhardt, Pavol Porvaz¹, Viera Revajová, \\ Božena Šoltysová ${ }^{1}$, Ján Blanár, Zuzana Sevčíková, Juraj Pistl \\ University of Veterinary Medicine, Košice, Slovak Republic \\ ${ }^{1}$ Slovak Centre of Agricultural Research Nitra, Agroecology Research Institute Michalovce, Slovak Republic
}

\author{
Received December 23, 2008 \\ Accepted March 8, 2010
}

\begin{abstract}
The effects of sage extract on the activity of intestinal alkaline phosphatase (AP), proliferative ability of enterocytes, and growth performance in chickens were studied during 42 days of the experiment under commercial conditions. A significant increase of body weight gain was found in chickens fed with sage extract in the grower period (17-29 days of age) and in the finisher period (30-42 day of age). Total serum proteins were significantly $(p<0.05)$ increased at 29 days of age in animals treated with sage extract. A significant $(p<0.001)$ decrease in activity of intestinal AP was demonstrated on 29 and 42 days in animals fed with sage extract complemented diet. Proliferative activity of enterocytes was increased $(p<0.01)$ in the finisher period along the duodenal villi in animals treated with sage extract. We conclude that the higher growth performance was probably due to improved endogenous secretion of the liver as a consequence of increased total proteins mainly in the grower period. Decreased activity of intestinal alkaline phosphatase was not in correlation with proliferative ability of enterocytes and the lower activity of AP could be influenced by improved digestion of lipids
\end{abstract}

Chickens, broilers, sage extract, alkaline phosphatase, enterocyte proliferative activity, growth performance

Recent trends and development in the area of animal nutrition have been characterized by an increasing interest in the potential impact of plants, herbs and spices on the animal growth performance.

Previous studies demonstrated that many Salvia species and their isolated constituents possess antioxidant activity (Zupko et al. 2001), antiinflammatory activity (Howes et al. 2003) and cholinesterase inhibition effect (Perry et al. 2001, 2003).

Mechanism for the interaction of plants including Salvia spp. with host organism may be related to intestinal and extraintestinal effects. Intestinal effects may be explained by the effects on the microflora (Taylor 2001) or intestinal mucosal system (García et al. 2007). Microflora can influence activities of certain enzymes involved in the metabolism uptake, and incorporation by enterocytes of dietary nucleic acids components (Whitt and Savage 1988).

Proliferative activity of enterocytes is the sign of healthy tissue turnover and maintenance (García et al. 2007). Unlike mammals, chicken enterocyte proliferation is not localized only in crypt region and the site of enterocyte differentiation is not precisely localized (Uni et al. 1998).

One of the crucial enzymes to altered function of the small intestine is alkaline phosphatase (AP) present mainly in the microvillous zone of absorption cells of intestinal villi (Bajin-Katič et al. 2006). The intestinal AP participates in the active capture and transport of lipids. Feeding a high-fat diet produced changes in the brushborder membrane lipid composition and increased intestinal AP activity (Kaur et al. 1996; Moze š et al. 2007). Activity of intestinal AP is the highest in the duodenal brush

University of Veterinary Medicine and Pharmacy

Komenského 73, 04181 Košice

E-mail: levkut@uvm.sk

Slovak Republic

http://www.vfu.cz/acta-vet/actavet.htm 
border, decreasing longitudinally to the large intestine with no activity in the stomach (Akiba 2007).

Earlier in vitro and in vivo experiments demonstrated that administration of sage oil extracts has a beneficial effect on activities of the digestive system of the body. For the present, however, there is no information about the effect of sage oil extract on the proliferative ability of enterocytes and expression of intestinal AP in relation to the growth performance of broilers.

\section{Materials and Methods}

Plant aromatic oil

The plant aromatic oil $(100 \% \mathrm{v} / \mathrm{v}$ [volume/volume]) was isolated from the leaves of sage (Salvia officinalis L., family Labiateae) by steam distillation of plant material in Calendula joint-stock company (Nová L'ubovňa, Slovak Republic). The percentile range of the main components was analysed by gas chromatography (GC) using Hewlett-Packard 5890 Series II (injection input split splitless, capillary column HP-5, detector FIF, automatic injector HP 7673) with nitrogen as carrier gas (Pavlišinová and Danielovič 2007). The percentile ranges of the main components of the aromatic oils utilized in the experiment are reported in Table 1.

Table 1. Gas chromatography analysis of sage aromatic oils $(100 \% \mathrm{v} / \mathrm{v})$ used in the experiment

\begin{tabular}{|l|l|c|}
\hline Plant source & Compound & Content (\%) \\
\hline \multirow{4}{*}{ Sage } & eucalyptol & 8.5 \\
\cline { 2 - 3 } & alpha-thujone & 14.8 \\
\cline { 2 - 3 } & beta-thujone & 7.2 \\
\cline { 2 - 3 } & camphore & 14.9 \\
\cline { 2 - 3 } & borneol & 3.7 \\
\hline
\end{tabular}
(broiler chicken). The animals had constant access to feed and water from identical fixtures. The broiler chicken flock studied for 42 days was fed with three commercial diets (BR1, BR2, BR3, Pol'nonákup DOMICA, Plešivec, Slovak Republic) with anticoccidicum salinomycin sodium and without antibiotics or growth promoters. The diets corresponded to the standards for broiler chickens in Feeding Norms for Poultry (1996). The herbal extract, aromatic oil isolated from sage (Salvia officinalis L., Labiateae) was included in the diet of the experimental group of chickens in a dosage calculated according to the thujone content $\left(507.3 \mathrm{ppm}-2.52 \mathrm{ml} \cdot \mathrm{kg}^{-1}\right)$ as well as according to the results of chemical and palatability tests.

Performance indicators

During the experiment the body weight of chickens was monitored at 7-days intervals. Feed was weighed

Table 2. Composition of the experimental diets $\left(\mathrm{g} \cdot \mathrm{kg}^{-1} \mathrm{DM}\right)$

\begin{tabular}{|l|r|rc|}
\hline & \multicolumn{3}{|c|}{ Experimental diets } \\
\hline Ingredients & $\begin{array}{r}\text { BR1 } \\
\text { days } \\
1-21\end{array}$ & $\begin{array}{c}\text { BR2 } \\
\text { days } \\
22-35\end{array}$ & $\begin{array}{c}\text { BR3 } \\
\text { days } \\
35-42\end{array}$ \\
\hline Crude protein & 347.23 & 258.73 & 240.84 \\
\hline Crude fat & 16.18 & 25.05 & 52.01 \\
\hline Crude fibre & 57.09 & 40.82 & 35.16 \\
\hline Crude ash & 85.45 & 67.15 & 62.12 \\
\hline Starch & 385.92 & 447.08 & 463.84 \\
\hline Total sugar & 48.67 & 67.23 & 58.13 \\
\hline Reducing sugar & 8.73 & 30.45 & 12.62 \\
\hline Calcium & 12.69 & 10.55 & 8.87 \\
\hline Phosphorus & 13.01 & 10.04 & 9.28 \\
\hline Sodium & 3.63 & 2.90 & 2.58 \\
\hline Methionine & 4.44 & 5.12 & 4.71 \\
\hline Lysine & 11.39 & 15.04 & 13.42 \\
\hline Cystine & 3.38 & 3.21 & 2.9 \\
\hline
\end{tabular}
on the same days to evaluate the feed consumption and feed conversion ratio.

Feed analysis

The experimental diets were dried at $102{ }^{\circ} \mathrm{C}$ for $16 \mathrm{~h}$ in a forced air oven and analysed for dry matter, crude protein, crude fat, crude fibre, and ash by methods of Javorský et al. (1987). The dietary amino acid were analysed using the AAA400 amino acid analyser (INGOS, Czech Republic) according to Regulation 1998/64 of European Community. Lysine was determined after hydrolysis with 6 $\mathrm{M} \mathrm{HCl}$, and methionine and cystine were determined after oxidative hydrolysis. The content of calcium, phosphorus and sodium were determined by atomic absorption spectrophotometry (AAS) with Shimadzu AA-6200 (Javorský et al. 1987). The nutrient analyses of the experimental diet are detailed in Table 2.

Blood and tissue samplings

Six randomly chosen chickens from 
each group at 2, 4, and 6 weeks of age were anaesthetized with intraperitoneal injection of xylazine (Rometar $2 \%$, SPOFA, Czech Republic) and ketamine (Narkamon 5\%, SPOFA, Czech Republic) at doses of 0.6 and $0.7 \mathrm{ml} \cdot \mathrm{kg}^{-1}$ body weight, respectively. After laparotomy, blood was collected into tubes by intracardial punction, samples for sera analyses were frozen and stored at $-20^{\circ} \mathrm{C}$. During the following necropsy the samples from the intestine were taken into the formalin for PCNA analysis, and into the nitrogen for histochemical analysis.

Biochemical and immunological assays

Serum total protein concentration $\left(\mathrm{g} \cdot \mathrm{l}^{-1}\right)$ was determined spectrophotometrically using the Bradford's method at $595 \mathrm{~nm}$ (Bradford 1976).

Serum total immunoglobulins were measured by zinc sulphate turbidity (ZST) reaction in modification of McEvan's method (McEvan et al. 1970). Briefly, $25 \mu$ of tested sera were mixed with $1.7 \mathrm{ml} 0.7 \mathrm{mmol} \cdot \mathrm{l}^{-1} 5.8$ $\mathrm{pH}$ zinc sulphate (208 mg $\cdot^{-1} \mathrm{l}$; Merck, Germany). The mixture was shaken, incubated for $2 \mathrm{~h}$ at room temperature and light absorption was measured photometrically at $590 \mathrm{~nm}$ (Spekol 11, Carl Zeiss, Jena, Germany). Blood serum mixed with PBS at the same ratio was used as the blank. The immunoglobulin contents of the tested sera were derived from a calibration curve plotted on a basis of turbidity values corresponding to four dilutions of the standard serum samples (Precinorm Protein, ROCHE Diagnostics, USA). Zinc sulphate turbidity reaction - the visual readings of the density of turbidity were performed by a comparative method. The turbidities of the tested samples, obtained by zinc sulphate reactions, were compared to the turbidities of five dilutions of the standard serum $\left(1.44,2.16,2.88,3.59,4.31 \mathrm{~g} \cdot \mathrm{l}^{-1}\right)$.

Serum content of calcium, phosphorus and sodium were determined by atomic spectrophotometric absorption spectrophotometry (AAS) with Shimadzu AA-6200 (Javorský et al. 1987).

\section{Histochemical assay}

The frozen tissue was cut $(7 \mu \mathrm{m})$ in a cryostat at $-25^{\circ} \mathrm{C}$, then tissue sections were transferred to supporting glass slides and air-dried. Demonstration of alkaline phosphatase activity was performed using a modified simultaneous azocoupling method (Lojda et al. 1979). The incubation medium contained naphtol ASBI phosphate (Sigma, Germany), Fast blue BB (Aldrich, Germany) and veronal acetate buffer (pH 9.2). The samples were incubated at $37^{\circ} \mathrm{C}$ for $10 \mathrm{~min}$, using the substrate concentration of $2.0 \mathrm{mmol} \cdot \mathrm{l}^{-1}$ and $\mathrm{pH}$ 8.9. Enzyme activity was analyzed cytophotometrically with a Vickers M85a microdensitometer. The measurements were performed using $\times 40$ objective, an effective scanning area of $28.3 \mu \mathrm{m}^{2}$ and scanning spot of $0.5 \mu \mathrm{m}$. The integrated absorbance was measured at a wavelength of $480 \mathrm{~nm}$. The mask was set over at least 30 brush border areas along the villus length in five sections of the jejunum. The AP activity was calculated as the absorbance values recorded by the instrument $/ \mathrm{min} / \mu \mathrm{m}^{3}$ brush border and their mean values were referred to one animal.

\section{Proliferating cell nuclear antigen (PCNA) assay}

Samples were taken from the caudal part of the duodenum, fixed in $10 \%$ neutral buffered formalin and embedded in paraffin. The examination of PCNA was carried out on the $5 \mu \mathrm{m}$ tissue sections with commercial Animal Research Kit (ARK) according to the special included protocol (DAKO, Denmark). The kit contained monoclonal mouse anti-PCNA antibody (Clone PC10; DAKO, Denmark) and all the components (peroxidase block, streptavidin HRP, blocking reagent, biotinylation reagent and DAB tablets) needed for examination. Negative controls were obtained by omitting the primary antibodies. The positively stained cells in three duodenal sections per animal were counted in a standardized area at the tip, middle, and at the base of villi. Five areas were selected at random from each of these sites using the ocular graticule LTD $0.25 \mathrm{~mm}$ IdXD rd (Tonbridge, Kent, UK). Measurements were performed using the light microscope (Nikon, Type 104, Japan) at a magnification of $\times 400$. Mean values and standard deviations were calculated.

Statistical analysis

The effect of essential sage oil on AP activity was analyzed by two-way ANOVA with post-hoc Fisher's LSD test. Data were expressed as mean \pm SEM and considered significant at $p<0.05$.

All other data were expressed as means \pm standard deviations (SD) of a single value (SAS, Version 8.2; SAS Institute Inc., 1999, Cary, NC USA). Means of the results from treatment were compared by one-way analysis of variance. Treatment means were statistically compared by Tukey-Kramer multiple comparison test. Significance was declared at $p<0.05, p<0.01$ and $p<0.001$.

\section{Results}

Percentage of the main components of the aromatic oils utilized in the trial is reported in Table 1.

Body weight gain (BWG), average daily feed intake (FI), and feed conversion ratio (FCR) are presented in Table 3. Significant increase of BWG was found in chickens fed with sage extracts within 17 - 29 and $30-42$ days of the experiment.

Concentrations of serum total proteins, total immunoglobulins (Ig) and macroelements 
Table 3. The effect of sage extract on growth performance (mean $\pm \mathrm{SD}$ )

\begin{tabular}{|c|c|c|c|c|c|c|c|c|c|c|c|}
\hline \multirow{3}{*}{ Group } & \multirow{3}{*}{$\begin{array}{l}\text { Initial } \\
\text { body } \\
\text { weight } \\
(\mathrm{g})\end{array}$} & \multirow{3}{*}{$\begin{array}{c}\text { Final } \\
\text { body } \\
\text { weight } \\
(\mathrm{g})\end{array}$} & \multicolumn{3}{|c|}{ Body weight gain (g/day) } & \multicolumn{3}{|c|}{ Average daily feed intake (g.day $\left.{ }^{-1}\right)$} & \multicolumn{3}{|c|}{ Feed conversion (g.g) } \\
\hline & & & \multicolumn{3}{|c|}{ Age (day) } & \multicolumn{3}{|c|}{ Age (day) } & \multicolumn{3}{|c|}{ Age (day) } \\
\hline & & & $1-16$ & $17-29$ & $30-42$ & $1-16$ & $17-29$ & $30-42$ & $1-16$ & $17-29$ & $30-42$ \\
\hline $\begin{array}{l}\text { Control } \\
\text { (C) }\end{array}$ & $\begin{array}{l}38.86 \\
\pm 6.71\end{array}$ & $\begin{array}{r}1746.67 \\
\pm 340.52\end{array}$ & $\begin{array}{r}14.55 \\
\pm 3.13\end{array}$ & $\begin{array}{r}36.87 \\
\pm 13.14^{\mathrm{a}}\end{array}$ & $\begin{array}{r}69.49 \\
\pm 17.99^{\mathrm{a}}\end{array}$ & $\begin{array}{r}29.39 \\
\pm 6.33\end{array}$ & $\begin{array}{r}80.45 \\
\pm 28.67\end{array}$ & $\begin{array}{r}160.63 \\
\pm 41.58\end{array}$ & 2.02 & 2.18 & 2.31 \\
\hline $\begin{array}{l}\text { Sage } \\
\text { (S) }\end{array}$ & $\begin{array}{r}40.57 \\
\pm 4.75\end{array}$ & $\begin{array}{r}1947.06 \\
\pm 274.14\end{array}$ & $\begin{array}{r}14.49 \\
\pm 3.24\end{array}$ & $\begin{array}{r}44.89 \\
+14.71^{b}\end{array}$ & $\begin{array}{r}98.19 \\
\pm 12.98^{\mathrm{b}}\end{array}$ & $\begin{array}{r}28.69 \\
\pm 6.42\end{array}$ & $\begin{array}{r}89.52 \\
\pm 29.33\end{array}$ & $\begin{array}{r}203.30 \\
\pm 26.87\end{array}$ & 1.98 & 1.99 & 2.07 \\
\hline
\end{tabular}

Means with different superscript letters in the same column differ significantly at $p<0.05$

Table 4. Values of biochemical indicators of broiler chickens (mean $\pm \mathrm{SD}$ )

\begin{tabular}{|c|c|c|c|c|c|c|c|}
\hline Age (day) & Group & $\begin{array}{c}\text { Total protein } \\
\left(\mathrm{g} \cdot \mathrm{l}^{-1}\right)\end{array}$ & $\begin{array}{c}\text { Total Ig } \\
\left(\mathrm{mg} \cdot \mathrm{dl}^{-1}\right)\end{array}$ & $\begin{array}{c}\text { Phosphorus } \\
\left(\mathrm{mg} \cdot \mathrm{dl}^{-1}\right)\end{array}$ & $\begin{array}{c}\text { Potassium } \\
\left(\mathrm{mg} \cdot \mathrm{dl}^{-1}\right)\end{array}$ & $\begin{array}{c}\text { Calcium } \\
\left(\mathrm{mg} \cdot \mathrm{dl}^{-1}\right)\end{array}$ & $\begin{array}{c}\text { Magnesium } \\
\left(\mathrm{mg} \cdot \mathrm{dl}^{-1}\right)\end{array}$ \\
\hline \multirow{2}{*}{16} & $\begin{array}{c}\text { Control } \\
\text { Sage }\end{array}$ & $\begin{array}{c}154.85 \pm 4.94 \\
153.99 \pm 2.8\end{array}$ & $\begin{array}{l}0.41 \pm 0.14 \\
0.33 \pm 0.15\end{array}$ & $\begin{array}{c}\mathrm{nd} \\
\mathrm{nd}\end{array}$ & $\begin{array}{c}\mathrm{nd} \\
\mathrm{nd}\end{array}$ & $\begin{array}{c}\mathrm{nd} \\
\mathrm{nd}\end{array}$ & $\begin{array}{c}\mathrm{nd} \\
\mathrm{nd}\end{array}$ \\
\hline \multirow{2}{*}{29} & Control & $115.08 \pm 5.65^{\mathrm{a}}$ & $1.25 \pm 0.54$ & $15.41 \pm 2.98$ & $19.07 \pm 1.4$ & $11.70 \pm 3.33$ & $3.09 \pm 0.44$ \\
& Sage & $120.64 \pm 5.19^{\mathrm{b}}$ & $1.09 \pm 0.36$ & $13.7 \pm 1.96$ & $20.27 \pm 2.85$ & $11.28 \pm 2.39$ & $3.03 \pm 0.45$ \\
\hline \multirow{2}{*}{42} & Control & $176.88 \pm 12.18$ & $1.14 \pm 0.35$ & $14.54 \pm 2.74$ & $20.32 \pm 2.72$ & $9.03 \pm 2.52$ & $2.68 \pm 0.48$ \\
& Sage & $181.14 \pm 7.16$ & $0.99 \pm 0.1$ & $12.91 \pm 1.83$ & $20.27 \pm 2.56$ & $12.01 \pm 3.51$ & $3.11 \pm 0.68$ \\
\hline
\end{tabular}

Means with different superscript letters in the same column differ significantly at $p<0.05$

Table 5. Alkaline phosphatase activity in jejunal microvillous zone (mean $\pm \mathrm{SEM})$

\begin{tabular}{|c|c|c|}
\hline Age (day) & Control & Sage \\
\hline 16 & $4.53 \pm 0.14$ & $4.57 \pm 0.06$ \\
\hline 29 & $4.87 \pm 0.07^{\mathrm{a}}$ & $3.74 \pm 0.07^{\mathrm{b}}$ \\
\hline 42 & $4.91 \pm 0.13^{\mathrm{a}}$ & $3.97 \pm 0.27^{\mathrm{b}}$ \\
\hline
\end{tabular}

Means with different superscript letters in the same line differ significantly at $p<0.001$

phosphatase activity on days 29 and 49 of the experiment.

are shown in Table 4 . The changes of serum total proteins were determined on day 29 of the experiment with a significant increase in animals fed the sage extract.

Activity of intestinal alkaline phosphatase in the jejunal microvillous zone is shown in Table 5. Administration of sage extract to the experimental group of chickens resulted in a significant decrease of jejunal alkaline duodenal villi of chickens in the finisher period (42 days) after feeding the diet complemented with sage extracts (Table 6).

Table 6. Numbers of enterocytes in duodenum and jejunum measured by PCNA assay (means \pm SD)

\begin{tabular}{|c|c|c|c|c|}
\hline Age (day) & \multicolumn{2}{|c|}{ Control } & \multicolumn{2}{c|}{ Sage } \\
\hline & duodenum & jejunum & duodenum & jejunum \\
\hline 16 & $15.87 \pm 1.00$ & $25.90 \pm 5.80$ & $19.67 \pm 2.70$ & $28.50 \pm 0,70$ \\
\hline 29 & $17.75 \pm 0.40$ & $23.27 \pm 3.30$ & $23.58 \pm 4.50$ & $24.90 \pm 4.40$ \\
\hline 42 & $14.70 \pm 2.70^{\mathrm{a}}$ & $18.52 \pm 2.20$ & $23.93 \pm 1.30^{\mathrm{b}}$ & $19.16 \pm 3.20$ \\
\hline
\end{tabular}

Means with different superscript letters in the same line differ significantly at $p<0.01$

\section{Discussion}

In order to optimize commercial conditions, the broilers were housed at a poultry production farm. Knowledge of the animal housing environment is essential for accurate interpretation of results from academic cage trials. Microbiological stresses on the animal are very important and they can be different in experimental cages than those encountered under current commercial conditions (Bedford 2000). 
Our results demonstrated a positive effect of sage extract-supplemented diet on body weight gain (BWG) during the grower period (17-29 days of age) and the finisher period (30-42 days of age). The beneficial effect of growth promoter substances on performance is related to a more efficient use of nutrients which in turn results in an improved feed conversion ratio - FCR (Elwinger et al. 1993). In this experiment, however, we found the tendency for improving FCR only in the experimental group during feeding. Similar results with significant changes in BWG and the lack of effect on FCR were obtained by García et al. (2007) who added hydroalcoholic plant extract from sage, thyme and rosemary leaves to the feed of broilers. A positive effect of aromatic oils isolated from sage and oregano on BWG in weaned pigs was also demonstrated by Marcin et al. (2006).

Our experiment also showed an increased level of serum total proteins in blood plasma of chickens. Total proteins include blood plasma proteins synthesized mainly in the liver such as albumin, clotting proteins, and globulins with significant extrahepatic role (Grieninger and Granick 1975). The sage extract is hepatoprotective and reveals anti-hepatotoxicity effect (Wynn and Fougére 2007). Increased BWG in experimental animals might be partly the result of improved hepatic functions and quantitative changes of proteins for the maintenance and performance of the body.

Demand for energy and protein for gut maintenance is higher compared to other organs. A fast growing broiler devotes about $12 \%$ of the newly synthesized protein to the digestive tract (Xu et al. 2003). Substances that are present in the digesta can lead relatively quickly to changes in the intestinal mucosa due to the close proximity of mucosal surface and the intestinal content. Activity of nutrient assimilation in the process of intestinal absorption is in close connection with the proliferative activity of enterocytes enhancing healthy tissue turnover and maintenance (García et al. 2007). The significant increase of enterocyte proliferation along the duodenal villi during the finisher period and the tendency for increased proliferative activity in other samplings found in our trial including some activity in the absorptive zone of villous epithelium demonstrate the beneficial properties of sage extract on proliferative ability of intestinal epithelial cells.

The current experiment demonstrated a significant reduction of mucosal alkaline phosphatase activity in chickens fed sage extract supplemented diet. The primary function of AP is splitting cholesterol and long chain fatty acids (Kaur et al. 1996). Dietary feed additives have been shown to work by a number of different mechanisms such as their ability to modify gut microflora and endogenous secretion of enzymes (Jakob et al. 2000). Borneol, a component of sage extract demonstrates beneficial properties stimulating the digestive system by increasing the production of gastric juices, and anti-inflammatory effects on the digestive system (Buchbauer et al. 1992; Juhás et al. 2008). It has been suggested that quantitative and qualitative changes of gastric juices in animals treated with sage extract might cause more efficient digestion and transportation of lipids in enterocytes. The decrease in AP found in experimental animals indicates a down regulation of the expression of this enzyme due to the beneficial effect of sage extract.

Our hypothesis is supported by the effect of sage extract on fatty acid profiles in the blood and breast meat (Koreleski and Świątkiewicz 2007; Szewczyk et al. 2006). Finally, the reduction of cholesterol has been observed in poultry (Wenk et al. 1998) and pigs (Szewczyk et al. 2006).

In contrast, the increase in intestinal AP activity may precede the development of obesity (Mozeš et al. 2000) and there is also evidence indicating the inverse relation between intestinal AP and the rate of fat absorption in obese animals (Mozeš et al. 2007). Activities of intestinal AP can be also influenced by microflora (Whitt and Savage 1988). For instance, sage demonstrates inhibitory activity in some bacterial strains (Marcin et al. 2006).

In conclusion, the results demonstrate that proliferative ability of enterocytes was not in 
direct correlation with the content of intestinal AP in animals treated with sage extract. It is supposed that the decreased activity of intestinal AP was induced by more efficient digestion of lipids in the digestive tract. Higher performance of the body was probably the result of improved endogenous secretion of the liver as a consequence of increased total proteins. Because of possible interaction (synergism) between the constituents, it remains rather unclear what compound of the ethereal oil acts as stimulator of the endogenous digestive enzymes, hepatoprotectant, antimicrobial agent, immunomodulator, or an unknown factor. However, further understanding of the mechanisms of the relations between sage extract and host are required to clarify the role of the extract in gut physiology.

\section{Vplyv šalviového extraktu na aktivitu alkalickej fosfatázy, proliferačnej aktivity enterocytov a rastové ukazovatele u kurčiat}

$\mathrm{V}$ priebehu 42 dní trvajúceho pokusu u kurčiat chovaných v komerčných podmienkach bol študovaný vplyv šalviového extraktu na aktivitu črevnej alkalickej fosfatázy, proliferačnú aktivitu enterocytov a rastové ukazovatele. Signifikantný ( $p$ $<0,05)$ nárast váhových prírastkov bol zistený u kurčiat po skrmovaní diéty obohatenej šalviovým extraktom počas fázy rastu (17-29 dní veku) a v konečnej fáze (30-42 dní veku). Celkové sérové proteíny boli signifikantne $(p<0,001)$ zvýšené u zvierat s prítomnost'ou šalviového extraktu v diéte. Signifikantný $(p<0,01)$ pokles aktivity črevnej alkalickej fostatázy bol zistený na 29. a 42. deň života u kurčiat kŕmených diétou s prídavkom extraktu šalvie. Proliferačná aktivita enterocytov bola signifikantne zvýšená v konečnej fáze rastu v duodenálnych klkoch u zvierat s obsahom šalviového extraktu v diéte. Predpokladáme, že vyššie produkčné ukazovatele mohli byt' spôsobené zvýšenou endogénnou sekréciou pečene, výsledkom čoho je aj zvýšenie celkových proteínov, hlavne v období rastu brojlerov. Pokles aktivity črevnej alkalickej fosfatázy nekoreloval s proliferačnou aktivitou enterocytov a nižšia aktivita alkalickej fosfatázy mohla byt' ovplyvnená zvýšenou digesciou tukov.

\section{Acknowledgement}

This work was supported by the Grant Agency for Science of Slovak Republic VEGA-1/3498/06, 1/0044/08, APVV20-041605 and project INFEKTZOON - Centrum of excellence for infections of animals and zoonoses, on the basis of support of operational program Research and development financed by European fund of regional development.

\section{References}

Akiba Y, Mizumori M, Guth PH, Engel E, Kaunitz JD 2007: Duodenal brush border intestinal alkaline phosphatase activity affects bicarbonate secretion in rats. Am J Physiol Gastrointest Liver Physiol 293: G1223-G1233

Bajin-Katic K, Stankov K, Dolai M, Kovačevic Z 2006: Intestinal alkaline phosphatase activity as a molecular marker of enterotoxicity induced by single dose of 5-fluorouracil and protective role of orally administered glutamine. Arch Oncol 14: 101-105

Bradford MM 1976: A rapid and sensitive for the quantitation of microgram quantities of protein utilizing the principle of protein-dye binding. Anal Biochem 72: 248-254

Bedford M 2000: Removal of antibiotic growth promoters from poultry diets: Implications and strategies to minimise subsequent problems. World's Poult Sci J 56: 347-365

Buchbauer G, Jager W, Jirovetz L, Meyer F, Dietrich H 1992: Effects of valerian root oil, borneol, isoborneol, bornyl acetate and isobornyl acetate on the motility of laboratory animals (mice) after inhalation. Pharmazie 47: $620-622$

Elwinger K, Daube G, Hommez J, Haesebrouck F 1993: In vitro susceptibility of Clostridium perfringens isolated from farm animals to growth-enhancing antibiotics. J Appl Bacteriol 75: 55-57

García V, Catalá-Gregori P, Hernández F, Megías MD, Madrid J 2007: Effect of formic acid and plant extracts on growth, nutrient digestibility, intestine mucosa morphology, and meat yield of broilers. J Appl Poult Res 16: $555-562$

Grieninger G, Granick S 1975: Synthesis and differentiation of plasma proteins in cultured embryonic chicken liver cells: a system for study of regulation of protein synthesis. Proc Nat Acad Sci USA 72: 5007-5011

Howes MJR, Perry NSL, Houghton PJ 2003: Plants with traditional uses and activities relevant to the management of Alzheimer's disease and other cognitive disorders. Phytother Res 17: 1-18 
Jakob S, Mosethin R, Zabielski R, Pierzynowski SG 2000: The influence of different vegetable oils on the exocrine pancreatic secretion in piglets. 6. Tagung Schweine-und Geflügelernährung, Lutherstadt. pp. 158-160

Juhás Š, Čikoš Š, Czikková S, Veselá J, Il'ková G, Hájek T, Domaracká K, Domaracký M, Bujňáková D, Rehák P, Koppel J 2008: Effects of borneol and thymoquinone on TNBS-induced colitis in mice. Folia Biologica (Praha) 54: 1-7

Javorský P, Fojtíková D, Kalaš V, Kratochvíl J, Schwarz M 1987: Chemical analyses in agricultural laboratories. Ministry of Agriculture and Nutrition of the Czech Republic, Prague, SNV Prague, the Czech Republic, 285 pp.

Kaur M, Kaur J, Ojha S, Mahmood A 1996: Dietary fat effects on brush border membrane composition and enzyme activities in rat intestine. Ann Nutr Metab 40: 269-276

Koreleski J, Światkiewicz S 2007: Dietary supplementation with plant extracts, xantophylls and synthetic antioxidants: effect on fatty acid profile and oxidative stability of frozen stored chicken breast meat. J Anim Feed Sci 16: 463-471

Lojda Z, Grossrau R, Schilber TH 1979: Enzyme histochemistry. Springer-Verlag Berlin, 59-70

Marcin A, Lauková A, Mati R 2006: Comparison of the effects of Enterococcus faecium and aromatic oils from sage and oregano on growth performance and diarrhoeal diseases of weaned pigs. Biologia Bratislava 61: 789-795

McEvan AD, Fisher EW, Selman IE, Penhale WJ 1970: A turbidity test for the estimation of immune globulin levels in neonatal calf serum. Clin Chim Acta 27: 155-163

Mozeš Š, Lenhardt L, Martinková A 2000: Alkaline phosphatase activity of duodenal enterocytes after neonatal administration of monosodium glutamate to rats. Physiol Res 49: 269-277

Mozeš Š, Šefćíková Z, Lenhardt L' 2007: Functional changes of the small intestine in over- and undernourished suckling rats support the development of obesity risk on a high-energy diet in later life. Physiol Res 56: 183-192

Pavlišinová A, Danielovič I 2007: The content of essential oil and major effective components of essential oil monitored in sage (Salvia officinalis L.). Proc. Slovak Centre of Agricultural Research - Institute of Agroecology 23: 205-212

Perry NSL, Houghton PJ, Sampson J, Theobald AE, Hart S, Lis-Balchin M, Robin J, Hoult S, Evans P, Jenner P, Milligan S, Perry EK 2001: In-vitro activity of S. lavandulaefolia (Spanish sage) relevant to treatment of Alzheimer's disease. J Pharm Pharmacol 53: 1347-1356

Perry NSL, Bollen CH, Perry EK, Ballard C 2003: Salvia for dementia therapy: review of pharmacological activity and pilot tolerability clinical trial. Pharmacol Biochem Behav 75: 651-659

Szewczyk A, Hanczakowska E, Swiatkiewicz M 2006: The effect of nettle (Urtica dioica) extract on fattening performance and fatty acid profile in the meat and serum lipids of pigs. J Anim Feed Sci 15 Suppl. 1: 81-84

Taylor DJ 2001: Effects of antimicrobials and their alternatives. Br Poult Sci 42 (Suppl.): 67-68

Uni Z, Platin R, Sklan D. 1998: Cell proliferation in chicken intestinal epithelium occurs both in the crypt and along the villus. J Comp Physiol B 168: 241-247

Zupko I, Hohmann J, Redei D, Falkay G, Janicsak G, Mathe I 2001: Antioxidant activity of leaves of Salvia species in enzyme-dependent and enzyme independent systems of lipid peroxidation and their phenolic constituents. Planta Med 67: 366-368

Wenk C, Scheeder M, Spleiss CH 1998: Sind Kräuter Allerheilsmittel? Schriftenreihe Inst Nutztierwissenschaften ETH Zürich 18: 95-108

Whitt DD, Savage DC 1988: Influence of indigenous microbiota on activities of alkaline phosphatase, phosphodiesterase I, and thymidine kinase in mouse enterocytes. Appl Environ Microbiol 54: 2405-2410

Wynn SG, Fougére BS 2007: Veterinary herbal medicine. In Materia Medica, Mosby Elsevier, St. Louis. Missouri, USA, pp 459-682

Xu ZR, Hu CH, Xia MS, Zhan XA, Wang MQ 2003: Effects of dietary fructooligosaccharide on digestive enzyme activities, intestinal microflora and morphology of male broilers. Poult Sci 82: 1030-1036 
